\title{
Accountancy in Horsebreeding Organization in Compliance with International Accountancy Standards
}

Faizrakhmanov Dz. I.

Kazan State Agrarian University, Kazan, 420015, Russia

Klychova G.S.

Kazan Federal University, Institute of Management, Economics and Finance, Kazan, 420008, Russia Kazan State Agrarian University, Kazan, 420015, Russia

Khametova M.V. Kazan State Agrarian University, Kazan, 420015, Russia Email:kgaukgs@mail.ru

\section{Doi:10.5901/mjss.2014.v5n24p111}

\section{Abstract}

The article deals with the issues of biological assets accounting in compliance with the international accountancy standard (IAS) 41; we have studied the IAS 41 and IAS 2 spheres of influence in horse breading accountancy by the stages of the production process, and offered the groups of biological assets in horse breading, which require generating of information in financial accounting compiled in compliance with the IAS. Improvement of the production costs accounting and analysis in horse breeding will allow fostering the accounting and information support of self-cost management and creating the necessary basis for taking clever management solutions aimed at the profit maximization.

Keywords: horse breeding, biological assets, international accountancy standard (IAS) 41, fair value.

\section{Introduction}

IAS selection as a basis of the domestic accountancy reforming demands more thorough study of the standards essence, their requirements, as well as evaluation of their application opportunities in the domestic accounting practice. Despite the fairly great attention paid to the systematic approach development towards the IAS introduction into the Russian accountancy practice, the issues of IAS complex interpretation remain still understudied. Thus, the research of IAS evaluation as an integral system being in close relationship with the systems of management accounting, audit, estimation, etc., is not fulfilled making the source of the certain problems, which occur by the IAS application.

\section{Theory}

International accountancy standards - are the documents containing the integral system of requirements governing the aims, application area, approval (accounting) scheme, estimation, presentation and disclosure of information on the separate accounting objects and types of activity in the financial accounting, which is rendered to the internal and external users by their effective managerial decisions making. International Financial Reporting Standards include International Accounting Standards developed by the former International Accountancy Standards Committee (IASC) and International Financial Reporting Standards - IFRS, developed by the International Accounting Standards Board (IASB) acting within the frames of the new International Accountancy Standards Committee Foundation (IASCF).

In compliance with the acting Conceptual framework the financial accounting shall be prepared basing on the following fundamental assumptions: the accrual basis means that the results of operations and other events shall be recognized whenever they occur, but not when the monetary funds or their equivalents are received or paid; going concern basis means, that the financial accounting is compiled on the basis of the assumption that the enterprise shall continue its activity in the nearest future, i.e. there is nether necessity nor the intention to considerably decrease the volume of operation and liquidate itself. 
The Conceptual framework indicates the following quality characteristics making information useful for the users: understandable, relevant, reliable, comparable one. The Conceptual framework reflects as well the concept of the "true and fair presentation", which is not determined as the quality characteristic, but indicates that the compliance of information to all listed quality characteristics allows truly and fairly representing of the financial state. The concept of the "true and fair presentation" is for the most part connected with the theoretically anticipated result - the reflection in the accountancy of the real state of the company. The existing Conceptual framework does not emphasize the present concept specially, nevertheless it is considered that by using the basic quality characteristics and corresponding standards the result will be of the "true and fair presentation".

Financial accounting shows the financial results of the events and other operations, herewith it groups them into broad categories in compliance with their economic characteristics.

The Conceptual framework emphasizes five basic elements of financial accountancy: assets, liabilities, own capital, profits and losses. Carrying out the comparative analysis of the financial accountancy elements in compliance with the Russian practice and IAS there is an opportunity to make conclusions of the differences existing in their formulations alongside with the certain similarity, stipulated by the application of these concepts in the practical activity of the Russian organizations.

Acceptance of the element in the financial accounting supposes its estimation. Estimation - is a process of the money magnitudes' evaluation in which the element of financial accounting is accepted and reflected in the balance and statement of profits and losses. The financial accounting may use different estimation methods.

The initial (historical) value:

- for assets - the sum of monetary funds or their equivalents, or the fair value at the moment of their acquisition;

- for liabilities - the sum of monetary funds or other revenues acquired as a result of the liabilities occurrence, or in some cases the sum of monetary funds planned for payment to meet the liability within the process of the normal economic activity.

The current value (or the reinstatement value - in the Russian accounting): for assets - the sum of monetary funds or their equivalents which should have been paid in the event the same or the equivalent commodity is purchased at present moment; for liabilities - non-discounted value of monetary funds or their equivalents, which was required to be spent for repayment of liabilities by the ordinary course of business. The American Conceptual framework uses the term the "replacement value" instead of the term the "current value". The realization (repayment) value: for assets- the sum, which can be acquired at present from sale of the asset in the ordinary conditions; for liabilities - non-discounted value of monetary funds, which is planned for payment to repay the liabilities in the course of the ordinary economic activity. One of the realizable value types is a net realizable value - a realizable value after deduction of realization costs. Capital (discounted) value: for assets - discounted value of future net cash inflow planned to receive from this asset in the process of the ordinary economic activity; for liabilities - discounted value of future net cash outflow, which presumably be required for liabilities repayment by the ordinary process of the company activity.

Apart from the indicated estimation types, the international standards use another ones, such as: recoverable amount of assets (IAS 36); fair value (IAS) 2, (IAS) 16, (IAS) 38, (IAS) 39, (IAS) 41. The economic literature very often reflects discussions regarding the possible alternative/additional approaches to the financial accounting estimation selection: additional auxiliary information disclosure; alternative types of estimation disclosure; use of opportunity of history alteration based on the unsupported assumptions; setting of requirements to the rendered warranties; provision of legal application procedures.

Thus we see, that IAS applies a lot of different types of the term "value" without giving definition of the term itself. To our opinion the Standards should give the following definition of the value: product or service worth expressed in the monetary unit, which may substantially vary under the influence of the goods or services market offer as well as their effective demand value.

\section{Results}

IAS 41 determines agricultural activity as the animals and plants (biological assets) bio transformation management for the purposes of realization, agricultural products acquisition or additional biological assets production.

Horse breeding, as per IAS - is a sub-brunch of agriculture engaged in horses bio transformation management for the purposes of horse breeding products realization (live horses, meet, kumiss-mare's milk, and dung), horse breeding products (kumiss, meet, and dung) acquisition, or production of the additional number of horses (foal crop).

IAS 41 establishes the biological assets accounting order in the period of their growth, degeneration, production and reproduction, as well as the order of the agricultural product initial estimation in the period of its picking. 
As applied to the horse breeding IAS establishes the order of horses accounting in the period of the young horses stock growth; degeneration - mortality, bad development, diseases, etc.; production in horse breeding, which partly coincides with the horses growth, and partly deals with the foal crop. The order of production accounting in this respect concerns the foal crop. Here belongs the reproduction of horses as well.

IAS 41requirements to evaluation of horses since the moment of the initial appreciation to the slaughter commencement: the evaluation shall be carried out by the fair value after deduction of the assumed sales costs, except cases, when at the moment of the initial appreciation it is impossible to determine the fail value with the sufficient reliability degree.

In cases, when it is impossible to determine the fair value of horses with the sufficient degree of reliability, it is necessary to be guided by the existing manuals of costs accounting in horse breeding, coordinated with the IAS 41 requirements. In this case, in compliance with the International standard IAS 41, the company should reflect the horses by their self-cost after deduction of the accumulated amortization and losses due to their depreciation. With the appearance of the horses' fair value estimation opportunity with the sufficient degree of reliability, the company should shift to the estimation by the fair value after deduction of the assumed sales costs.

IAS 41 shall be applied in the process of the following horse breeding objects accounting in cases, when they are connected with the agricultural activity:

1) mature horses, raised horses, foal crop - as biological assets;

2) mature horses before slaughter, mare's milk, raw skins, raw horse meat as of the slaughter moment, dung as of the moment of its receipt - is the agricultural product as of the moment of its picking;

3) state subsidies to the horse breeding, both of the federal and of the local sub-federal entities.

The process of milk production and slaughter correspond by the essence to the harvesting process, its procedure is determined in the IAS 41, where the cropping means "Separation of the product from the biological asset or termination of the vital activity of the biological asset". The process of horses' butchering is usually called slaughter, thus, the horses slaughter shall be considered the cropping in compliance with the IAS 41. There is a clear separation in the domestic horse breeding practice of the milk yield from the kumiss production. Here the kumiss production is related to the agricultural product processing in the terms and definitions of IAS 2.

There is one more specific type of products - the sperm. By its characteristics it is actually similar to the definition of the biological asset. Nevertheless, by the definition given in IAS 41, paragraph 5, biological assets embrace animals and plants, but sperm - is a microorganism, a cell and belongs to the realm of microorganisms. Proceeding from this sperm should be attributed to the agricultural products.

The Table 1 represents conclusions by the fields subject to accounting in horse breeding as per the IAS 41 and IAS 2.

Table 1. Separation by the spheres of influence between IAS 41 and IAS 2 in horse breeding accountancy by the stages of production process

\begin{tabular}{|c|c|c|c|c|c|}
\hline \multicolumn{4}{|c|}{ IAS 41 } & \multicolumn{2}{c|}{ IAS 2 } \\
\hline \multirow{2}{*}{ Biological asset } & $\begin{array}{c}\text { Additional biological } \\
\text { asset production }\end{array}$ & $\begin{array}{c}\text { Agricultural } \\
\text { product cropping }\end{array}$ & $\begin{array}{c}\text { Agricultural } \\
\text { product }\end{array}$ & $\begin{array}{c}\text { Agricultural product } \\
\text { processing }\end{array}$ & $\begin{array}{c}\text { Product acquired as a result } \\
\text { of processing after cropping }\end{array}$ \\
\hline & Foal crop & Sperm collection & Sperm & $\begin{array}{c}\text { Special processing } \\
\text { and freezing }\end{array}$ & Frozen sperm \\
\cline { 2 - 6 } (butchering) & $\begin{array}{c}\text { Milk } \\
\text { Meat }\end{array}$ & Milk processing & Kumiss \\
\hline $\begin{array}{c}\text { Horses in the } \\
\text { process of rising }\end{array}$ & & Meat & $\begin{array}{c}\text { Carcass } \\
\text { preparation }\end{array}$ & Food meat \\
\cline { 3 - 6 } & & Dung collection & Dung & Dung processing & Organic fertilizers \\
\hline
\end{tabular}

As per IAS 41 "Biotransformation consists of the following processes: growth, degeneration, production and reproduction, resulting in qualitative and quantitative alterations in the biological asset" and "Group of biological assets - is a combination of similar animals or plants".

The group of the "homogenous" biological assets shall include horses as technologically and historically formed sub-branch of the human activity.

In respect of the horse breeding, biotransformation of horses consists of the following processes: growth, 
degeneration, and reproduction resulting in the quantitative and qualitative alteration of horses.

The degeneration is construed in IAS 41 as "the decrease in the amount of the animals and plants or degradation of their qualitative characteristics". Degeneration in horse breeding means the potential milk quality disruption resulting from horses' disease or mechanical damage of the animal's body, or the decrease in the horses' inventory due to the mortality. As a result it brings about depreciation or decrease of the potential fair value of milk, meat, and kumiss. The issues of monetary evaluation of the horse breading products received in the degeneration conditions are totally regulated by IAS 41.

For the financial result determination IAS 41 requires the procedure of recognizing and evaluation of the biological asset, as well as the products received from the biological asset.

As applied to horse breeding, IAS 41, paragraph 10 determines, that the company shall recognize biological asset - live horses or agricultural product - milk, meat, kumiss, when:

1) the company controls the asset as a result of the previous events. This refers to getting the foal crop in a definite estation and its raising. Live horses can be purchased as well - in this aspect they are also allowed for recognition in compliance with the considered requirement. As this item refers simply to the asset regardless of its being biological or any other type, so milk, meat and kumiss received in the estation or accepted from the population for the further processing and sale also fall under its requirements;

2) the company has a probability of getting future economic benefits from this asset. This item refers to the definitions of the product and the goods. Horse breeding construes milk, meat and kumiss as the products. Nevertheless, it is commonly known that the definition of the marketability level is characteristic of agriculture; it shows the market share of the product for sale in the total volume of the manufactured products.

The part of the product, which by virtue of technological reasons shall not be directed to sale, and shall be used for some other purposes, which in their turn will facilitate acquisition of additional commercial product - acquisition of the future economic benefits, still must be recognized for accounting as per the present item of

IAS 41. Milk, which will go for the foals rearing, can be attributed to such type of product, as well as meat and kumiss going to the company canteen for making commercial dishes; or natural payment by the horse breeding products. The products of horse breeding consuming in company for personal needs free of charge shall fall outside the scope of this item. Here belong free lunches (made only of horse meat), free giveaway of horse meat (to the employees, rural men etc.), kumiss and horse meat meant for using as gifts, that is all, which not in the least attracts any potential investors, as it will not give any future direct economic benefits (though these positions may be accounted as organization costs);

3) fair value, or self-cost of the asset may be evaluated with the good enough reliability level. At the impossibility to determine the fair value, the domestic norms regulation base allows determining the horses and horse breeding products' self-cost quite reliably, provided the regulation base has been complied with and the respective accounting guided by the IAS 41requirements has been carried out.

Paragraph 30 of IAS 41 reads, "There is an assumption regarding the fair value of the biological asset determination possibility with the sufficient degree of reliability. This assumption may be denied only at the moment of the initial recognition of the biological asset failing to submit any information regarding its market prices and indexes, whereas the alternative calculations of the fair value are most evidently not reliable. In this case biological asset shall be evaluated by the self-cost after deduction of accumulated amortization and losses due to their depreciation. Upon occurrence of opportunity to determine the fair value of biological asset with the sufficient enough reliability level, the company shall shift on to the evaluation by the fair value after deduction of the assumed sale costs".

For the foal crop value determination at the moment of the initial recognition, we recommend to calculate the historical value (self-cost) after the deduction of the accumulated amortization and losses due to their depreciation.

Algorithm of the foals' crop evaluation by the initial recognition will be the following:

1) if there is an opportunity to sell the foal's meat, such foals shall be evaluated by the price of the last transaction of such kind or by the declared price for such meat at the market plus the sale price after the deduction of the assumed sales costs;

2) if there is no opportunity to sell the foal's meat due to its low physical qualities (insufficient fat quantity, etc.) and respectfully the absence of the market, the foals shall be evaluated by the normative self-cost after the deduction of amortization and losses due to their depreciation.

Normative self-cost in this case is calculated judging from the cost of 60 feeding days of the mares' breeding till the moment, when the physical parameters of the foal allow to use its meat for sale, divided by the number of foals. The costs volume is acquired judging from the data of the previous period corrected for the inflation.

All the succeeding horses evaluation shall be carried out by the fair value of meat and kumiss determined judging from the prices at the active market (retail trade, fairs, etc.). 
This provision is regulated by IAS 41, paragraph 31, which indicates, that if the company has ever evaluated the biological asset by the fair value after deduction of the assumed sales costs, the aforesaid biological asset shall be reflected by the fair value after deduction of the assumed sales costs up to the moment of its disposal.

The most substantiated prices at evaluating of meat and kumiss by the fair value will be the prices, which has been worked out in the market.

At the insufficient substantiation of the prices taken from the channel other than sales through the active market, one should be guided by IAS 41, paragraph 16:

"The companies would very often conclude agreements stipulating the sale of biological assets or agricultural products on a definite day in future. By determination of the fair value one should not always be guided by the prices indicated in the agreements, as the fair value reflects the current range of prices at which the buyer and the seller are ready to sign the agreement. Thus, the availability of the agreement is not necessarily followed by the correction of the fair value for the biological asset or agricultural product. In special cases the biological asset or agricultural product sales agreement may occur onerous in compliance with the definition cited in the International Standard IAS 37 "Estimated liability and contingent assets". The International Standard IAS 37 provisions are applied to the onerous agreements".

The active market of horse meat and kumiss operation practice uses establishment of several market prices: minimal, maximal and average. As per IAS, and basing on the principle of diligence it will be appropriate to use minimal price for the purposes of estimation and accounting.

The fair value of the horses' estimation procedure consists of the following stages:

1) expert estimation of the horses' size (as well as their potential meat and milk yield) and their quality parameters (fat, nutrition substances, etc.);

2) the minimal price is determined in compliance with the price set in the market judging from the definite quantitative and qualitative parameters of meat, milk and kumiss; so the price estimation of horses is carried out by multiplying the horses quantity in the group by the received price.

At termination of the production cycle of horses' raising at the moment of their slaughter, the meat in any case must be estimated by the fair value. As per IAS 41 in respect of the horse breading products (agricultural products) the estimation shall be carried out by the fair value set in the moment of the horses' slaughter (cropping) after deduction of the assumed sales costs. Such estimation shall become the self-cost of the horse breeding product as of the date of the IAS 2 "Reserves" application commencement. Judging from the slaughter technology, the horse breeding products cropping and the IAS 2 "Reserves" application commencement dates coincide.

To make the fair value estimation easier, the IAS 41, paragraph 15 gives the following recommendations: "Fair value of the biological asset or agricultural product is easier for determination provided the biological assets or agricultural products are grouped by the main characteristics, for instance, age or quality. The company chooses main characteristics judging from those used at the market for the price formation basis".

The following groping mode is characteristic of the horse breeding products:

1. Horse breeding products - mare's milk, growth and weight gain, horse raising products, horses' malt wool, horses' raw hair, horses' work, horses' dung.

2. Horses' livestock - stud stallions and teasers' livestock, stud horses, mares over 3 years old, teaser stallions, working horses, workhorses engaged on the agricultural work, other stallions and altered horses over 3 years old, stud horses over 3 years old.

3. Foal horses - young stock of stud horses from 3 to 4 years, young stock of stud horses from 2 to 3 years, young stock of stud horses from 1 to 2 years, young stock of stud horses before 1 year, altered horses of all ages, young stock of horses from 1 to 3 years, foals after 1 year after the weaning, foals before the weaning.

4. Young stock of horses by gender or age - stud mares over 4 years, stud colts from 3 to 4 years, stud fillies from 3 to 4 years, colts before 3 years, fillies before 3 years.

In compliance with the IAS 1, paragraph 54, information on the biological assets' cost shall be presented with the separate line in the balance sheet.

IAS 1, paragraphs 66 and 67, allows (obliges) separating of the article "Biological assets" into the sub-classes both in the balance sheet and in the footnotes to the balance. It is expedient to separate minimum two sub-classes of the articles in the accounting of the organizations dealing with horse breeding: biological assets value - horse breeding; biological assets value - other enterprises of agriculture.

Such division of the article shall be important for the potential information consumers regarding the organization activity dealing with horse breeding, as it clearly separates the value of biological assets belonging to horse breeding and the value of biological assets belonging to the other enterprises of agriculture, which the organization is engaged in.

The domestic instructional guidelines and accountancy forms stipulate the reflection of such information. However, 
there the balance value is detached from the other qualitative indexes of biological assets, whereas IAS 41, paragraph 43 , emphasizes the necessity to divide balance value according to the groups of biological assets basing on the definite qualitative and quantitative features.

IAS 41 does not establish a strict list of groups and classification features of biological assets, leaving this procedure to the organizations. Herewith, the organizations must open principles forming the basis of the used classification. We recommend the biological assets' groups of horse breeding, which need information forming in the financial accounting made in compliance with IAS (Table 2).

Table 2. Horse breeding biological asserts' groups made in compliance with IAS 41

\begin{tabular}{|c|c|c|c|c|c|c|c|c|}
\hline \multicolumn{2}{|c|}{$\begin{array}{l}\text { Types of biological } \\
\text { assets }\end{array}$} & \multirow{2}{*}{$\begin{array}{l}\text { Groups of } \\
\text { horse } \\
\text { breeding } \\
\text { assets } \\
\begin{array}{c}\text { Main animal } \\
\text { stock }\end{array}\end{array}$} & \multicolumn{6}{|c|}{ Horses' groups by the gender and age groups } \\
\hline \multirow{3}{*}{ Mature } & Yielding & & $\begin{array}{l}\text { Stud stallions } \\
\text { and teasers }\end{array}$ & Studhorses & $\begin{array}{c}\text { Кобылы старше } \\
3 \text { лет }\end{array}$ & $\begin{array}{l}\text { Working } \\
\text { horses }\end{array}$ & \begin{tabular}{|c|} 
Altered \\
horses over \\
3 years \\
\end{tabular} & $\begin{array}{l}\text { Studhorses } \\
\text { over } 3 \text { years }\end{array}$ \\
\hline & \multirow[t]{2}{*}{ Consumed } & $\begin{array}{l}\text { Horses for } \\
\text { slaughter }\end{array}$ & $\begin{array}{l}\text { Stud young } \\
\text { stock of } \\
\text { horses of all } \\
\text { ages }\end{array}$ & $\begin{array}{c}\text { Altered horses of } \\
\text { all ages }\end{array}$ & $\begin{array}{c}\text { Young stock of } \\
\text { horses from } 1 \text { to } \\
3 \text { years }\end{array}$ & $\begin{array}{c}\text { Foals after the } \\
\text { weaning } \\
\text { before } 1 \text { year }\end{array}$ & $\begin{array}{l}\text { Foals before } \\
\text { the weaning }\end{array}$ & $\begin{array}{l}\text { Working } \\
\text { horses }\end{array}$ \\
\hline & & Sperm & $\begin{array}{l}\text { Stud stallions } \\
\text { and teasers }\end{array}$ & Studhorses & $\begin{array}{c}\text { Studhorses over } \\
3 \text { years old }\end{array}$ & \multicolumn{3}{|c|}{-} \\
\hline Immature & $x$ & $\begin{array}{c}\text { Raising young } \\
\text { stock }\end{array}$ & $\begin{array}{l}\text { Stud young } \\
\text { stock of } \\
\text { horses of all } \\
\text { ages }\end{array}$ & $\begin{array}{l}\text { Young stock of } \\
\text { horses from } 1 \text { to } \\
3 \text { years }\end{array}$ & $\begin{array}{l}\text { Foals before and } \\
\text { after the weaning }\end{array}$ & \multicolumn{3}{|c|}{ - } \\
\hline
\end{tabular}

Improvement of the production costs accounting and analysis in horse breeding will allow fostering the accounting and information support of self-cost management and creating the necessary basis for taking clever management solutions aimed at the profit maximization.

\section{Conclusion}

Thus the development of market relations and the entry of Russia in WTO have increased the integration process and broadened cooperation between organizations not only within the country, but on the international level as well, which demands the provision of reliable information to the marker subjects regarding the financial state of the counter agents. Such situation causes objective necessity in transition to the accounting principles complying with the International Accounting Standards (IAS) and development of new instructive guidelines in the accountancy. It has stipulated the emergence of the new accounting category in agriculture - "biological assets" embracing into one group such accounting objects as plants and animals. The present absence of the scientifically based techniques and provisions of accountancy in the system of its normative and legal regulating hinders the objective estimation and accounting of biological assets. In this respect the studying of the theoretical basics, the current practice analysis, development of methodological provisions and practical recommendations in biological assets accounting improvement are essential for the theory, methodology and practice.

\section{References}

Alborov R.A. Biological assets accounting by the fair value in compliance with IAS 41 "Agriculture" / R.A. Alborov, S.M. Kontsevaya, E.V. Fastova // Economy of agricultural and processing enterprises - 2007. - No1. - pp. 33-39

Vakhrushina M.A. International accountancy standards: textbook / M.A. Vakhrushina // M.: Read Group, 2011. - 656 pg.

Getman V.G. International accountancy standards: textbook N.G. Getman. - M.: Finances and Statistics, 2009. - 656 pg.

Klychova G.S. Financial results of the agricultural organizations accounting in compliance with the IAS / G.S. Klychova, M.M. Zalaltdinov, M.A. Zyabbarov. - Kazan: Publishing House of the Kazan University, 2005. - 159 pg.

Klychova G.S. Production accounting of costs in horse breeding organization / G.S. Klychova, A.R. Zakirova, M.V. Khametova // Bulletin of the Kazan State Agrarian University. - 2013. - V. 28. - No2. - pp. 29-25. 
Klychova G.S., Iskhakov A.T. Solar batteries application and electrical power accounting in agriculture // Mediterranean journal of social sciences. - 2014. - No 12. -pp. 187-191.

Kozmenkova S.V. Application peculiarities of IAS 41 "Agriculture" in the Russian accounting and reporting practice / S.V. Kozmenkova, E.N. Shatinal/ International Accountancy. - 2010. - No 16 (148). - pp. 2-7.

International accountancy standards. - M.: Askeri-ASSA, 2011.- 998 pg.

Pyatov M.L. Agricultural products accounting and information disclosure in compliance with IAS 41 / M.L. Pyatov and I.A. Smirnova [Electronic resource]. - Access mode: http://www.buh.ru/document-1522

CH.T. Horngren, Foster. J., 2000. Accounting: administrative aspect: trans. from English. / Ed. Ya.V.Sokolova. Moscow: Finance and Statistics, 576 p. (in Russian) 